\title{
THE COUPLING BETWEEN ENTREPRENEURSHIP AND PUBLIC POLICY: TIGHT IN DEVELOPED COUNTRIES BUT LOOSE IN DEVELOPING COUNTRIES
}

\author{
LA CONEXIÓN ENTRE EL EMPRENDIMIENTO Y LA \\ POLÍTICA PÚBLICA: BIEN AJUSTADA EN LOS PAÍSES \\ DESARROLLADOS, PERO SUELTA EN LOS PAÍSES EN DESARROLLO
}

\author{
Thomas Schøтt, Рн.D.* \\ Kent Wickstrøm Jensen, Ph.D.**
}

\begin{abstract}
In this paper we compare the coupling between entrepreneurship policy and entrepreneurship activity in developed and developing countries. Using new institutional arguments, we argue that developing countries are prone to implement policies that (1) are based on experiences in developed countries which have not proven to transfer fittingly to developing economies, (2) are only partly implemented and are not internally consistent as a result of a lack of resources to do so, and (3) are more beneficial on paper than on actual activity. Following this perspective, the coupling between entrepreneurship policy and entrepreneurship activity is hypothesized to be lower for developing countries than for developed countries. Using GEM data correlating the TEA index of early-phase entrepreneurship with indicators of policies obtained from key expert informants supports this proposition.
\end{abstract}

Key words: Entrepreneurship policy, entrepreneurship activity, developed vs. developing countries.

\section{Resumen}

Este trabajo compara el enlace entre las políticas pro emprendimiento y la actividad emprendedora en los países desarrollados y los países en desarrollo. Utilizando los argumentos de la nueva institucionalidad, exponemos que los países en desarrollo son propensos a aplicar políticas que: (1) se basan en experiencias en los países desarrollados pero que no han demostrado ser trans-

* Associate Professor and National Team Leader, GEM Denmark, Department of Entrepreneurship and Relationship Management, University of Southern Denmark, Denmark. e-mail: tsc@sam.sdu.dk

** Assistant Professor, Department of Entrepreneurship and Relationship Management, University of Southern Denmark, Denmark. e-mail: kwj@sam.sdu.dk 
feridas correctamente a las economías en desarrollo; (2) son sólo parcialmente implementadas y no son internamente coherentes como resultado de la falta de recursos para aplicarlas, y (3) son más beneficiosas "sobre el papel" que en la actividad real. A raíz de esta perspectiva, el acoplamiento entre la política y el emprendimiento plantea la hipótesis de que este enlace es menor para los países en desarrollo que para los países desarrollados. La correlación del índice de emprendimiento en etapas iniciales, TEA, del GEM con indicadores de políticas públicas obtenidos de encuestas a expertos, apoya esta afirmación.

Palabras clave: Política pro emprendimiento; actividad emprendedora; países desarrollados vs. en desarrollo.

JEL Classification: L26, L56, M13, O57.

\section{INTRODUCTION: THE COUPLING BETWEEN TWO SECTORS}

There is a long history of national governments intervening in national as well as international business environments to support the competitiveness of national companies and industries and to stimulate national economic growth (Gilbert et al., 2004). In the same way, changes in perceptions of local as well as global economic structures have been highly influential in redefining public policy and government intervention. It has here been the general assumption that the better the coupling between economic structures and national policy, the higher national economic growth.

One of the most significant changes in the global economic structures during the last decades has been what Acs (1984) terms as a shift from a managerial towards an entrepreneurial capitalism. Increased speed of scientific and technological development has led to increasingly dynamic and competitive business environments (Huber, 2004). Along with increased instability and turbulence across industries, economic growth has become increasingly attributed to new firms and new market entrants offering new product and services, smaller firms with flatter and more responsive hierarchical structures, and entrepreneurial firms fit for radical innovations (Acs and Szerb, 2007).

While the increasing importance of entrepreneurship for economic growth has widely transferred into national as well as international political agendas, not all national governments have been equally successful in devising policies that have generated economic growth. Notably, developing countries have been significantly less able to stimulate national economic growth when compared to developed countries. Easterly (2001) reports, that whereas median per capita income growth in developing countries in 1960-1979 was 2.5 percent, it declined to 0.0 percent in 1980-1998 - a period that Easterly terms as "the lost decades".

In this paper, we propose that part of the answer for these lost decades is a looser coupling between entrepreneurship policy and entrepreneurship activity in developing countries as compared to developed countries. We argue that the lack of economic growth in developed countries is not caused by a lack of entrepreneurship policy to support entrepreneurial activity per see, but rather a consequence of the circumstance that the entrepreneurship policies in develop- 
ing countries are less fit for the local economic and cultural contexts in which they are implemented (Meyer et al., 1997), and that the coupling between policy and action is looser in developing countries than in developed countries (Drori, 2003).

Based on arguments from institutional theory (DiMaggio and Powell, 1983; Meyer et al., 1997), we first consider the conditions under which a tight versus a loose coupling between policy and activity is likely to occur. Next, we formulate the hypotheses that for developed countries there will be a tight coupling between entrepreneurship policy and entrepreneurship activity, whereas for developing countries there will be a loose coupling between entrepreneurship policy and entrepreneurship activity.

We then test these hypotheses using data from the GEM (Global Entrepreneurship Monitor) research program. Specifically, we correlate the TEA (Total Entrepreneurship Activity) index and the Opportunity-TEA (that part of the entrepreneurship activity, which is motivated by opportunity rather than necessity) of early-phase entrepreneurship with indicators of entrepreneurship policies obtained from key expert informants. Secondly, using the HDI (Human Development Index), we test for a linear interaction effect of development and policy on entrepreneurship activity. Finally, we discuss the implications of the results for entrepreneurship policy in developing countries.

\section{Coupling between Entrepreneurship Policy and Entrepreneurial ACtivity}

As defined by Glassman (1973) coupling denotes the extent to which two system elements either have few variables in common, or if the common variables are weak compared to other variables which influence the system elements. Yet, the conceptualization of tight versus loose coupling extends beyond that of interdependence between system elements. As noted by Weick (1976) loose coupling describes a situation in which elements are responsive to one another yet retain much separateness and identity. This conceptualization of loose coupling allows system elements to, on the one hand, act rationally on the technical level, while on the other, being faced with indeterminateness on the institutional level being exposed to outside forces (Orton and Weick, 1990).

It is this property of simultaneously being linked with some degree of interdependence and subject to change, indeterminateness and independence, which justifies the use of the concept of coupling to describe the relationship between entrepreneurship policy and entrepreneurial activity. As described by Weick (1982, p. 380) loose coupling exists when elements affect each other "suddenly (rather than continuously), occasionally (rather than constantly), negligibly (rather than significantly), indirectly (rather than directly), and eventually (rather than immediately)". In the coupling between public policy and entrepreneurial activity, loose coupling exists when public policy is decoupled from entrepreneurial activity in the sense that whilst public policy is set up to support entrepreneurship, it is possible that the effect on entrepreneurial activity is negligible and perhaps even insignificant.

From an institutional perspective, people engaged in policy-making are much more enactors of scripts from institutionalized worldwide models defin- 
ing legitimate agendas for local action, than they are actors pursuing rational responses to internal and external contingencies (Meyer et al., 1997). Coercive isomorphism will tend to drive decision makers towards conformity with the expectations of actors in the larger and stronger economic environment and in particular to the expectations of those on whom they depend for resources (DiMaggio and Powell, 1983; Pfeffer and Salancik, 1978). Furthermore, through mimetic processes, decision-makers faced with the uncertainty represented by ambiguous means to ends relationships, will tend to follow the actions of those whom they perceive as most successful. Finally, normative isomorphism due to a highly professionalized and world wide tightly connected scientific field leading the world view on the relationships between policy factors and entrepreneurship may lead into a high similarity in the enactment of national identities as well as national policy, even if significant differences exist among the societies.

Yet, from a functional perspective, elements of worldwide models are often not internally consistent and are often poorly fitted to local practices. In addition, elements of world models are often adopted eclectively and diffused at various levels. In turn these inconsistencies form the basis for a loose coupling between purpose and structure, between intentions and results, and hence disconnect between policy and activity is likely to result (Meyer et al., 1997). Yet, decoupling is more likely to exist under some circumstances.

Loose coupling between policy and activity is most likely to exist when there is a general belief in policies as tools for performance achievements, while there is a lack of a consistent program by which to implement such policies (Drori, 2003). Under such circumstances policy-makers working with scarce resources will find it easier to adopt elements from world models than to establish local customized solutions and they will be more prone to engage in planning for, rather than implementing, facilitating structures (Meyer et al., 1997).

As argued above, there is a globalized consensus about the importance of entrepreneurship for economic growth (Caree and Thurik, 2003; Acs and Audretsch, 2003). This is so even though recent findings have indicated that entrepreneurship plays different roles for different countries dependent on the stage of economic development (Wennekers et al., 2005; van Stel et al., 2005). In particular, highly developed countries tend be further along in the transition from a managed economy towards an entrepreneurial economy (Audretsch and Thurik, 2001) and tend to be those that have the highest economic benefits from entrepreneurial activity (Carree and Thurik, 1999).

Elaborate entrepreneurial policies implemented by national governments across North America, Europe and East Asia (Brett et al., 2004) reflect the firm belief of politicians in the economic benefits that can be accrued from initiating national entrepreneurship policies and programmes. Yet, the question still remains as to whether there actually exist a coherent program for policy makers striving to increase economic growth by supporting entrepreneurship activities?

Secondly, a review of recent empirical studies on entrepreneurship policy (Acs and Szerb, 2007) reveals several inconsistencies not only in terms of which aspects of public policy have significant impacts on entrepreneurial activity, but also in terms of the direction in which policy variables affect entrepreneurship activity. Acs and Szerb (2007) point to differences in local economic structures in order to explain some of these discrepancies. A caution is made, that whilst by far the most empirical and theoretical research is developed from the perspective 
of American, European, and other countries like Japan with well established financial, political, and educational structures etc., findings from here may not apply equally well to countries with less developed economies.

\section{COUPLING BETWEEN ENTREPRENEURSHIP POLICY AND ACTIVITY IN DEVELOPED COUNTRY VERSUS DEVELOPING COUNTRY}

Several conditions indicate that coupling between entrepreneurship policy and activity should be high in developed countries while looser in less developed countries. The availability of resources in a country not only affects the likelihood of a fit between scripts from the world models and the local practices of the country, but also affects the ability of the country to adopt such scripts for national policy, planning and activity.

First, developed countries direct more political and scientific resources toward examining the field of entrepreneurship developing and testing theoretical models with policy implications. The focus of this effort is primarily -yet not exclusively- directed at testing and developing models that are fit for the economic structures of the developed countries. Studies by Drori (2003) have further shown that the coupling between science and policy is looser in developing countries than it is in developed countries. This means that more elaborate models exist to describe entrepreneurship in developed economies than in developing economies.

Moreover, due to the comparatively better performance of developed countries and due to more elaborated institutional structures, scientific as well as political institutions in developed countries will have a higher status in the worldwide community. This in turn implies that developed countries have higher impact on the creation of particular scripts contained in the world model. As a result, world models are more likely to be fit to local practices in developed countries and less fit to local practices in developing countries.

Secondly, adopting entrepreneurship policy scripts from the world model toolbox may necessitate a substantial amount of resources available for the local government in order to implement the necessary actions to support local entrepreneurship. Given that less developed countries do not have such resources; it is likely that even if scientific recommendations are included in public policies, that implementation of the necessary activities will not happen accordingly. As described by Meyer et al. (1975), under such circumstances, state managers may simply retreat to planning for future progress or they may even make do with incorporating principles from the scripts into general statements of values and identity (Meyer et al., 1997).

Finally, the resource scarcity of less developed countries implies that these countries will depend more on their ability to negotiate favourable condition for the exchange of resources with developed countries. This resource dependence may lead governments of less developed countries to favour the legitimacy that can be attained from adapting policies that are consistent with the expectations and world views of developed countries on whom they depend for resources. One example of this is the conditional lending policies of the World Bank and the IMF starting in the 1980s in which lending was made conditional on the implementation of specific economic policies (Easterly, 2001). 
In sum, the ambiguity of means to ends regarding the policy interventions and entrepreneurial activity, a dominance of developed countries in the development of scripts for world models of entrepreneurship policy, a relative looser coupling between these world models and the practices of developing countries, and a high institutional pressure on developing countries to adopt these models combined with resource constraints limiting their ability to do so, are all factors suggesting a looser coupling between entrepreneurship policy and activity in developing countries as compared to developed countries.

The above neoinstitutionalist theorizing leads us to formulate three hypotheses regarding the effect of country development on the coupling between public policy and entrepreneurial activity.

1. For the developed countries, the coupling between entrepreneurship and policy within a country will be tight.

2. For the developing countries, the coupling between entrepreneurship and policy within a country is looser, typically, than within a developed country.

3 . The more developed a country is, the tighter the coupling between entrepreneurship policy and activity.

Following Meyer et al. (1997) and Drori (2003), coupling is measured as correlation across a set of countries. Tight coupling would be indicated by a correlation that is positive and substantial

Looser coupling would be indicated by a correlation that is lower, much lower. So the three hypotheses can be specified in a directly testable manner. First, for the developed countries, the correlation between entrepreneurship and policy is positive and substantially strong. Second, for the developing countries, the correlation between entrepreneurship and policy is lower, i.e. lower than the correlation for the developed countries. Third, among all countries, the entrepreneurial activity depends not only on policy by itself but also on the interaction between policy and development, and this interaction effect is positive so that entrepreneurial activity is tied to policy to the extent that the country is developed.

\section{DATA: GLOBAl ENTREPRENEURSHIP MONITOR'S POPUlATION SURVEY AND EXPERT ASSESSMENT}

The data for the analysis is from the GEM (Global Entrepreneurship Monitor) that annually investigates entrepreneurship and its conditions in many countries around the world (www.gemconsortium.org). For each participating country, the GEM project provides measures of the rate of entrepreneurial activity and indicators of entrepreneurial policies. The indicators have included the same set since 2003, so we analyse the countries that have participated in the period 2003-07.

\section{Indicators of entrepreneurship activity}

We include two indicators of entrepreneurship in a country. First, entrepreneurship in a country is indicated as a rate, the rate of working-age adults who are involved in starting a new enterprise, a percentage. This rate is the well-known 
TEA-index, Total Entrepreneurial Activity in the early phase. This is obtained in the GEM Adult Population survey of at least 2000 adults in each country in each year of participation.

Secondly, as a second index, we use the Opportunity-TEA. Opportunity-TEA is a sub-index of the overall TEA-index and measures the rate of working-age adults involved in starting a new enterprise, whose motivation to start a new business is based on perceived business opportunities. By using this index, we control for the fact that much entrepreneurial activity in developing countries is driven by necessity.

\section{Indicators of policy}

Policy is indicated in several areas by asking experts in each country to assess their quality, as reviewed in the following.

Entrepreneurial policies shall he be indicated by fifteen indicators. An indicator denotes a measurement that is acknowledged to be far from perfect. The indicators shall be presented, and then we shall consider limitations on reliability and validity. We have indicators for the following fifteen policy domains:

Financial resources $(A)$

Government policy $(B)$

Public programs $(C)$

Educational programs (D)

Technology transfer $(E)$

Commercial and legal infrastructure $(F)$

Internal market openness $(G)$

Physical infrastructure $(H)$

Entrepreneurial values (I)

Entrepreneurial opportunities $(K)$

Entrepreneurial skills $(L)$

Esteem of the entrepreneurial vocation $(M)$

Intellectual property rights $(N)$

Equal rights for both genders $(P)$

Entrepreneurial growth policies $(Q)$

Each indicator is tapped by several questions (the questions are shown at www.gemconsortium.org, identified by the above letters A, B, C, etc.). For example "Government policy" in each country, in Denmark in the following illustration, is tapped by asking experts to ascertain the truthfulness of each of the following statements,

"In Denmark, government policies (e.g. procurement) consistently favour new firms."

"In Denmark, the support for new and growing firms is a high priority for policy at the national government level."

"In Denmark, the support for new and growing firms is a high priority for policy at the local government level."

"In Denmark, new firms can get most of the required permits and licenses in about a week." 


\section{"In Denmark, the amount of taxes is not a burden for new and growing firms.”}

"In Denmark, taxes and other government regulations are applied to new and growing firms in a predictable and consistent way."

"In Denmark, coping with government bureaucracy, regulations and licensing requirements is not unduly difficult for new and growing firms".

Each statement is rated by the expert as Completely false, Somewhat false, Neither true nor false, Somewhat true, Completely true, as a scale from 1 to 5. The ratings of each statement obtained from the experts in the country (usually more than 40 experts in a year) are then averaged across the experts (the ratings of a statement correlate highly across experts so they can appropriately be averaged across experts) and then averaged across the statements as an annual indicator for the domain (the statement-measures for a domain correlate highly, so they can appropriately be averaged), and we then average the annual indictors across the four years 2003-06 (the annual indicators correlate highly from year to year, so they can appropriately be averaged across the years), as our indicator of the domain in the country.

The indicators for the domains are highly correlated across countries. All their correlations are positive and they are 0.5 on average. Therefore the indicators for each country can appropriately be averaged into an overall index of entrepreneurship policy in the country. The overall index of entrepreneurship policy correlates 0.85 with the indicator for "Government policy" and correlates about 0.7 with the various indicators, on average, so the combination has high reliability as an overall indicator and is especially closely correlated with the indicator of government policy. In short, we have fifteen indicators that are rather reliable, and an overall index with higher reliability.

As indicators of the concept of entrepreneurship policy in a country, how valid are these indicators. The above quoted statements are explicitly about policies toward entrepreneurial endeavours, so the indicator "Government policy" has high face validity. The other indicators are less explicitly about national policy, but more about cultural and institutional arrangements that result from entrepreneurship policy, perhaps less directly, perhaps also from many other policies and other conditions in society. Indeed, the statements were not formulated by the GEM research program in order to measure policy in itself, but to measure various institutional and cultural framework conditions. So the other indicators do not have as high face validity as that of "Government policy", when we use them as indicating entrepreneurship policy.

However, the fact that the various indicators are all fairly highly correlated with the one indicator, Government policy, that has high validity, shows that they have some degree of validity. Notably, the overall index correlates highly with the indicator of Government policy and therefore has rather high validity.

In short, the indicators are rather reliable, and the index is especially reliable. As indicators of entrepreneurship policy, the indicator of Government policy probably has the highest validity, and perhaps considerably higher than the others, but also the overall index has high validity. Accordingly, our analysis and conclusions shall rely primarily on the indicator "Government policy", rely secondarily on the overall indicator, and rely less on the other indicators. 


\section{Economic development as a dichotomy and as a continuum}

Development, as a path that countries tend to evolve along, is often considered as a dichotomy, especially when contrasting high and low development. The countries are then termed developed countries and developing countries. The 60 countries available for this study are categorized as 37 developed and emergent countries and 23 developing countries.

The developed countries are: Australia, Austria, Belgium, Canada, Croatia, Czech Republic, Denmark, Finland, France, Germany, Greece, Hong Kong, Hungary, Iceland, Ireland, Israel, Italy, Japan, Latvia, Netherlands, New Zealand, Norway, Poland, Portugal, Puerto Rico, Republic of Korea, Romania, Russia, Singapore, Serbia, Slovenia, Spain, Sweden, Switzerland, Taiwan, United Kingdom and United States.

The developing countries are: Argentina, Brazil, Chile, China, Colombia, Dominican Republic, Ecuador, India, Indonesia, Jamaica, Jordan, Kazakhstan, Mexico, Malaysia, Peru, Philippines, South Africa, Thailand, Turkey, Uganda, United Arab Emirates ${ }^{1}$, Uruguay and Venezuela.

This dichotomy is of course a simplified representation of the more complex reality of development. Alternatively, development may be considered as a continuum, ranging from high to low through a continuous scale. Development can be measured by the Human Development Index, HDI. The index combines income, life expectancy, literacy and education, on a scale between 0 and 1 . This index is available for all 60 countries in our study, based mainly on information from 2004 (United Nations Development Program, 2006).

\section{Analyses}

Our classification into developed countries and developing countries is almost a dichotomization of the Human Development Index. Nearly all developed countries have higher HDI than nearly all developing countries, and the inconsistencies are few and small in that only a few developed countries are slightly below a few developing countries. The mean HDI for the developed countries is significantly higher than the mean HDI for the developing countries (Table 1).

Policy differs between developed countries and developing countries. Developed countries tend to have more elaborate policies than developing countries, Table 1. Their difference is significant. Policy and Human Development Index tend to go hand in hand, they are positively correlated, and their correlation is 0.33 .

Entrepreneurship also differs between developed countries and developing countries, Table 1. Developed countries tend to have less entrepreneurship than developing countries. Their difference is significant. Entrepreneurship and Human Development Index are correlated; their correlation is negative, -0.57 . This negative correlation between development and entrepreneurship captures

\footnotetext{
Although United Arab Emirates could be consider a developed economy by his GDP per capita, in this study we consider their average indexes of HDI that are lower than developed countries.
} 
TABLE 1

HIGHEST AND LOWEST COUNTRIES AND MEANS FOR DEVELOPED AND

DEVELOPING COUNTRIES, FOR HUMAN DEVELOPMENT INDEX, POLICY, ENTREPRENEURSHIP AND OPPORTUNITY-ENTREPRENEURSHIP

\begin{tabular}{|c|c|c|c|c|c|}
\hline & & & $\begin{array}{c}\text { Mean } \\
\text { among the } \\
\text { developed } \\
\text { countries }\end{array}$ & $\begin{array}{c}\text { Mean } \\
\text { among the } \\
\text { developing } \\
\text { countries }\end{array}$ & $\begin{array}{c}\text { Correlation } \\
\text { with HDI }\end{array}$ \\
\hline \multicolumn{3}{|c|}{ Human Development Index } & 0.92 & 0.75 & \\
\hline \multirow{3}{*}{ Highest } & Norway & 0.97 & & & \\
\hline & Iceland & 0.96 & & & \\
\hline & Australia & 0.96 & & & \\
\hline \multirow{3}{*}{ Lowest } & India & 0.61 & & & \\
\hline & Malaysia & 0.58 & & & \\
\hline & Uganda & 0.50 & & & \\
\hline \multicolumn{3}{|l|}{ Policy } & 3.0 & 2.8 & 0.33 \\
\hline \multirow{3}{*}{ Highest } & United States & 3.7 & & & \\
\hline & U. Arab E. & 3.6 & & & \\
\hline & Taiwan & 3.5 & & & \\
\hline \multirow{3}{*}{ Lowest } & Japan & 2.4 & & & \\
\hline & Uruguay & 2.4 & & & \\
\hline & Ecuador & 2.3 & & & \\
\hline \multicolumn{3}{|c|}{ Entrepreneurship (TEA) } & 6.4 & 16.4 & -0.57 \\
\hline \multirow{3}{*}{ Highest } & Peru & 35.5 & & & \\
\hline & Uganda & 30.5 & & & \\
\hline & Ecuador & 27.4 & & & \\
\hline \multirow{3}{*}{ Lowest } & Russia & 3.4 & & & \\
\hline & Puerto Rico & 3.1 & & & \\
\hline & Japan & 2.6 & & & \\
\hline \multicolumn{3}{|c|}{ Opportunity-entrepreneurship } & 4.9 & 10.8 & -0.48 \\
\hline \multirow{3}{*}{ Highest } & Peru & 24.7 & & & \\
\hline & Ecuador & 18.2 & & & \\
\hline & Uganda & 16.8 & & & \\
\hline \multirow{3}{*}{ Lowest } & Puerto Rico & 2.4 & & & \\
\hline & Russia & 2.4 & & & \\
\hline & Japan & 1.9 & & & \\
\hline
\end{tabular}

Note: The means are based on 37 developed and 23 developing countries. Each difference in a pair of means is significant, the difference for policy has a one-sided p-value of 0.01 and the other differences have p-values less than 0.0001 . 
a tendency toward a negatively sloping line, but there is also a tendency toward a U-shape.

Opportunity-driven entrepreneurship, likewise, differs between developed countries and developing countries, Table 1. Developed countries tend to have less opportunity-driven entrepreneurship than the developing countries. Opportunity-driven entrepreneurship and Human Development Index are negatively correlated; their correlation is negative, -0.48 . This negative correlation between development and opportunity-entrepreneurship again captures a tendency toward a negatively sloping line, but there is also a tendency toward a U-shape.

\section{Developed countries: Testing for tight coupling between entrepreneurship policy and activity}

The first hypothesis is that, within a developed country, the coupling between entrepreneurship and policy is typically tight. The hypothesis, more specifically, is that, across the developed countries, the correlation between policy and practice is positive and substantially strong.

The correlation can be computed for each indicator of policy, listed in Table 2.

TABLE 2

CORRELATION, FOR THE DEVELOPED COUNTRIES, BETWEEN EACH POLICY-INDICATOR AND TEA AND ALSO OPPORTUNITY-TEA. THE P-VALUE IS SHOWN WHERE BELOW .10 IN A ONE-TAILED TEST

\begin{tabular}{|c|c|c|}
\hline & \multicolumn{2}{|c|}{ Correlation } \\
\hline & TEA & Opportunity-TEA \\
\hline Index of entrepreneurship policy (combined) & $0.33 * *$ & $0.44 * *$ \\
\hline Government policy (B) & 0.20 & $0.29 * *$ \\
\hline Financial resources $(\mathrm{A})$ & 0.13 & 0.20 \\
\hline Public programs $(\mathrm{C})$ & 0.08 & 0.18 \\
\hline Educational programs (D) & $0.23 *$ & $0.29 * *$ \\
\hline Technology transfer $(\mathrm{E})$ & 0.13 & $0.22 *$ \\
\hline Commercial and legal infrastructure $(\mathrm{F})$ & 0.19 & $0.29 *$ \\
\hline Internal market openness $(\mathrm{G})$ & $0.23 *$ & 0.12 \\
\hline Physical infrastructure $(\mathrm{H})$ & $0.21 *$ & $0.33 *$ \\
\hline Entrepreneurial values (I) & $0.45 * *$ & $0.46 * *$ \\
\hline Entrepreneurial opportunities (K) & $0.56^{* *}$ & $0.65 * *$ \\
\hline Entrepreneurial skills (L) & $0.49 * *$ & $0.49 *$ \\
\hline Esteem of the entrepreneurial vocation (M) & 0.21 & 0.21 \\
\hline Intellectual property rights $(\mathrm{N})$ & $0.22 *$ & $0.39 * *$ \\
\hline Equal rights for both genders $(\mathrm{P})$ & 0.16 & $0.33 * *$ \\
\hline Entrepreneurial growth policies (Q) & $0.25 *$ & $0.37 * *$ \\
\hline
\end{tabular}

Note: Each correlation is based on 37 developed countries, except that the correlations for growth policies are based on 29 countries.

* One-tailed p-values between 0.05 and 0.10 .

** One-tailed p-values below 0.05 . 
Table 2 shows that the correlations are all positive. Indeed, they are all above 0.1 . Seven of the fifteen specific indicators have statistically significant correlations (indeed, it is surprising that with such a statistically small $\mathrm{N}$ we obtain so many significant correlations). The overall index is also statistically significant and is substantially strong. The first hypothesis is thus corroborated.

That the indicators have a correlation with TEA that is positive (albeit not all are statistically significant, which is not surprising because the $\mathrm{N}$ is rather small), in accordance with theory, grants criterion validity to the indicators as tapping the concept of entrepreneurship policy.

The positive correlation is also illustrated in Figure 1, which plots the developed countries according to their policy (the combined index of entrepreneurial policy) and their entrepreneurial activity (TEA).

\section{FIGURE 1}

DEVELOPED COUNTRIES PLOTTED ACCORDING TO POLICY (OVERALL INDEX)

AND ENTREPRENEURSHIP (TEA). (TWO COUNTRIES ARE OVERLAID)

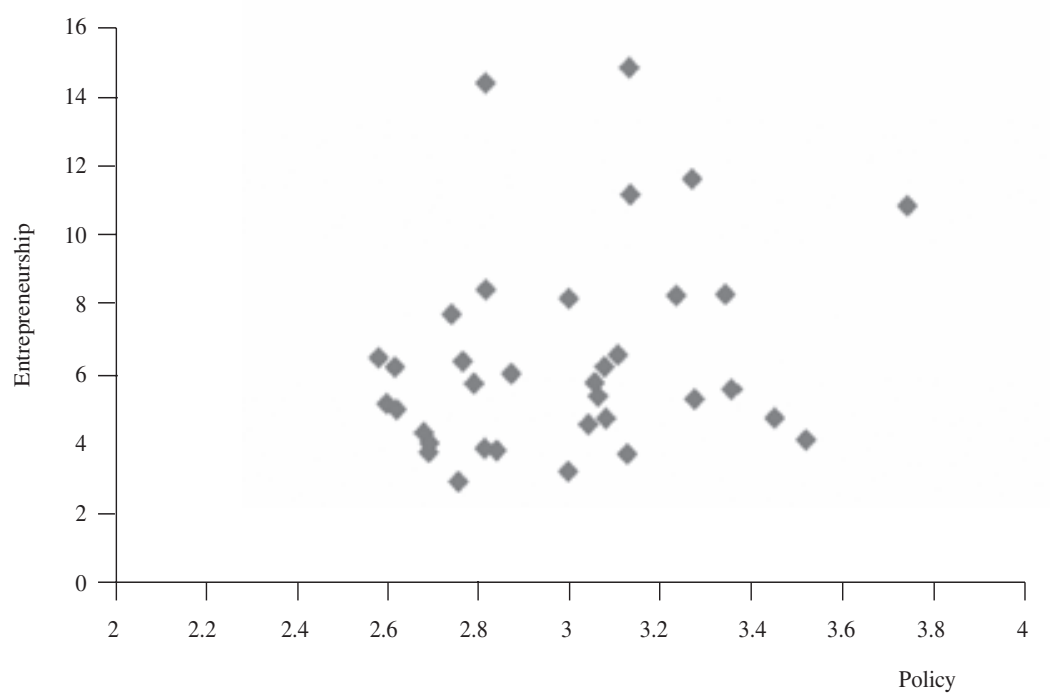

\section{Developing countries: Testing for looser coupling between policy and practice}

The second hypothesis is that the coupling between entrepreneurship and policy is looser within a developing country, typically, than the coupling within a developed country. More specifically, the hypothesis is that the correlation between policy and practice, for developing countries, is lower than the correlation between policy and practice, for the developed countries.

Table 3 shows the correlations for each indicator of policy, for the developing countries, with TEA and Opportunity-TEA respectively. Contrasting with the results for the developed countries in Table 2, we see that for every indicator 
the correlation for the developing countries is lower than the correlation for the developed countries, indeed, far lower. The largest difference is for the overall index (not so surprising because this probably is our most reliable measure).

TABLE 3

CORRELATION, FOR THE DEVELOPING COUNTRIES, BETWEEN EACH POLICY-INDICATOR AND TEA, AND ALSO OPPORTUNITY-TEA

\begin{tabular}{|l|c|c|}
\hline & TEA & Opportunity-TEA \\
\hline Index of entrepreneurship policy & $-0.41^{*}$ & -0.33 \\
\hline Government policy (B) & -0.33 & -0.26 \\
\hline Financial resources (A) & $-0.45^{* *}$ & -0.32 \\
\hline Public programs (C) & $-0.40^{*}$ & -0.34 \\
\hline Educational programs (D) & -0.33 & -0.30 \\
\hline Technology transfer (E) & $-0.57^{* *}$ & $-0.48^{* *}$ \\
\hline Commercial and legal infrastructure (F) & $-0.41^{*}$ & -0.25 \\
\hline Internal market openness (G) & -0.26 & -0.20 \\
\hline Physical infrastructure (H) & -0.25 & -0.18 \\
\hline Entrepreneurial values (I) & -0.15 & -0.19 \\
\hline Entrepreneurial opportunities (K) & -0.11 & -0.05 \\
\hline Entrepreneurial skills (L) & -0.28 & -0.18 \\
\hline Esteem of the entrep. vocation (M) & -0.04 & -0.11 \\
\hline Intellectual property rights (N) & $-0.58^{* *}$ & $-0.50^{* *}$ \\
\hline Equal rights for both genders (P) & -0.04 & -0.03 \\
\hline Entrepreneurial growth policies (Q) & -0.29 & -0.23 \\
\hline
\end{tabular}

Note: For the developing countries, each correlation is based on 23 countries, except that the correlations for growth policies is based on 20 developing countries.

* One-tailed p-values between 0.05 and 0.10 .

** One-tailed p-values below 0.05 .

The negative correlation for the developing countries is illustrated in Figure 2, which plots the developing countries according to their policy (the combined index of entrepreneurial policy) and their entrepreneurial activity (TEA).

These large differences between the developing countries and the developed countries show that the coupling between policy and practice is much looser in the developing countries than in the developed countries.

As an aside, we note that the correlations are actually quite negative in the developing countries. This suggests that the framework conditions that GEM measures do not promote entrepreneurship in the developing countries. 


\section{FIGURE 2}

DEVELOPING COUNTRIES PLOTTED ACCORDING TO POLICY (OVERALL INDEX) AND ENTREPRENEURSHIP (TEA).

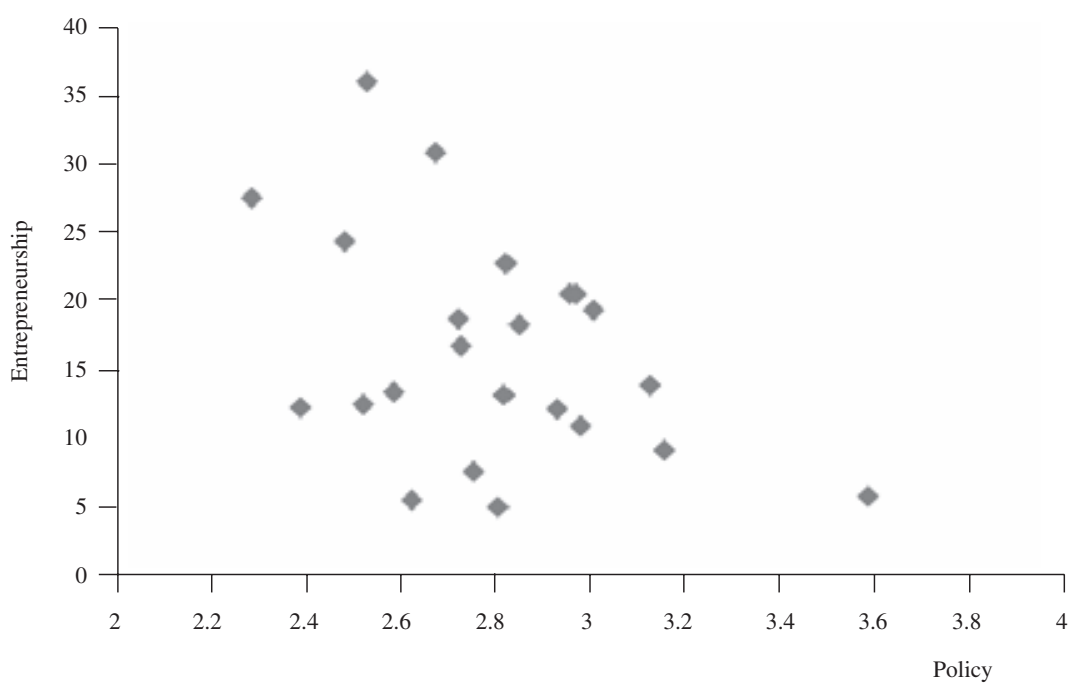

\section{Further tests of the effect of development upon coupling}

Our hypotheses that development is related to coupling between policy and entrepreneurship, that coupling is strong when development is high and weak when development is low, can be tested further by regression modeling.

The effect of development upon the association between policy and entrepreneurship can be specified as a statistical interaction effect. Policy and entrepreneurship is not linearly related but is stronger related when development is high. Entrepreneurship is not just linearly related to policy, but a boost is added when policy and development are high. This addition may be modeled as the product of development and policy, development* policy. How entrepreneurship relates to both policy and development may therefore be modeled by the expression:

Entrepreneurship $=\mathrm{a}+\mathrm{b}$ Development $+\mathrm{c}$ Policy $+\mathrm{d}$ Development $*$ Policy

This is a multiple regression model with an interaction term. Our hypothesis is that the coefficient $d$ for the interaction is positive. Opportunity-entrepreneurship may be modeled similarly.

This model can be estimated using the dichotomous operationalization of development, so that development is measured as a dummy variable that is 0 for the developing countries and 1 for the developed countries. The model can be estimated for TEA and also for Opportunity-TEA (Table 4). 
The regression equation for TEA, as we have estimated the coefficients in Table 4, can be written as:

$$
\mathrm{TEA}=49-52 \text { Development }+(15 \text { Development }-12) \text { Policy. }
$$

TABLE 4

REGRESSION OF TEA, AND OF OPPORTUNITY-TEA, ON POLICY, DEVELOPMENT (DUMMY), AND THEIR INTERACTION

\begin{tabular}{|l|c|c|}
\cline { 2 - 3 } \multicolumn{1}{c|}{} & TEA & Opportunity-TEA \\
\hline Policy & -12 & -6 \\
\hline Development (dummy) & -52 & -34 \\
\hline Development*Policy & 15 & 10 \\
\hline Constant & 49 & 28 \\
\hline
\end{tabular}

Note: Both regressions are based on 60 countries. The interaction is significant in the first regression with one-tailed p-value 0.001 , and significant in the second regression with one-tailed p-value 0.003 .

So for the developed countries (when Development is 1), the equation becomes:

$$
\text { TEA }=-3+3 \text { Policy }
$$

This expresses a positive relationship, expressing that the coupling between policy and TEA for a developed country is positive, so to some extend this is a tight coupling.

For the developing countries (when Development is 0 ), the estimated regression equation for TEA becomes:

$$
\mathrm{TEA}=49-12 \text { Policy }
$$

This expresses a relationship that appears negative, and much below the positive relationship for developed countries, so it expresses that the coupling for a typical developing country is not strong, but is much looser than the coupling for a typical developed country.

Opportunity-entrepreneurship, as also modeled in Table 4, can likewise be considered. The estimated regression equation for Opportunity-TEA can be written as:

Opportunity-TEA = 28 - 34 Development + (10 Development -6$)$ Policy.

So for the developed countries, the equation for Opportunity-TEA becomes:

Opportunity-TEA $=-6+4$ Policy 
This expresses a positive relationship, a coupling between policy and opportunity-TEA for the developed country which is at least somewhat tight.

For the developing countries (when Development is 0), the estimated regression equation for Opportunity-TEA becomes:

$$
\text { Opportunity-TEA = } 49-12 \text { Policy. }
$$

This expresses a negative relationship, a coupling for a typical developing country, which is looser than the coupling for a typical developed country. These regressions of TEA and Opportunity-TEA, using the dichotomous measure of development, lend further support for the conclusions that the coupling of policy with entrepreneurship (and also with opportunity-entrepreneurship) typically is tight in a developed country and that the coupling typically is looser in a developing country.

These hypotheses can also be even further tested using the continuous conception of development as operationalized by the Human Development Index. With this continuous measure we can estimate a similar regression equation, Table 5.

TABLE 5

TEA AND OPPORTUNITY-TEA REGRESSED ON POLICY, HUMAN DEVELOPMENT INDEX, AND THEIR INTERACTION

\begin{tabular}{|l|c|c|}
\cline { 2 - 3 } \multicolumn{1}{c|}{} & TEA & Opportunity-TEA \\
\hline Policy & -102 & -59 \\
\hline Human Development Index & -361 & -214 \\
\hline HDI*Policy & 113 & 67 \\
\hline Constant & 333 & 195 \\
\hline
\end{tabular}

Note: Both regressions are based on 60 countries. The interaction is significant in the first regression with one-tailed p-value 0.001 , and significant in the second regression with one-tailed p-value 0.003 .

The regression equation for TEA, with the estimated coefficients in Table 5, can now be written as:

$$
\text { TEA }=333-361 \text { HDI + (113 HDI - 102) Policy }
$$

So when HDI exceeds 102/113 or 0.9 (so the country is developed), then the coefficient for Policy is positive, and the equation expresses a relationship between policy and TEA which is positive, a coupling for the developed country which is at least somewhat tight. But when HDI is much less than 0.9 (so the country is a developing country), then the coefficient for Policy is negative and the relationship between policy and TEA is negative, a coupling for a developing country which is looser than the coupling for a developed country. 
The regression equation for Opportunity-TEA, with the estimated coefficients in Table 5, can be written as:

$$
\text { Opportunity-TEA = } 195-214 \text { HDI + (67 HDI }-59) \text { Policy }
$$

So when HDI exceeds 59/67 or 0.9 (so the country is developed), then the coefficient for Policy is positive, and the equation expresses a relationship between policy and Opportunity-TEA which is positive, a coupling for the developed country which is at least somewhat tight. But when HDI is much less than 0.9 (so the country is developing), then the coefficient for Policy is negative, and the relationship between policy and Opportunity-TEA is negative, a coupling for a typical developing country which is looser than the coupling for a typical developed country.

In short, these regressions of TEA and Opportunity-TEA, also using the continuous measure of development, lend even further support for the conclusions that the coupling of policy with entrepreneurship (and also with opportunityentrepreneurship) tends to be tighter as development is higher.

\section{Discussion and Conclusions}

Our starting point was a theory about coupling between practice and policy within a country, adopted from studies of science and its policy (Meyer et al., 1997; Drori, 2003). Specifically, the theoretical hypothesis was that practice and policy are tightly coupled in a typical developed country but looser coupled within a developing country. We tested this hypothesis using data from the Global Entrepreneurship Monitor. The rate of entrepreneurship is measured by the TEA-index and the Opportunity-TEA index. Policy toward entrepreneurship is indicated by fourteen expert ratings from the GEM survey plus a combined index. These indicators are available for the period 2003-07 covering 60 countries, classified as 37 developed countries and 23 developing countries. We further used the Human Development Index as an indicator of a country's stage of development.

The correlations and the linear regression models in the analyses all support our hypothesis that the coupling between entrepreneurship policy and practice is tight in developed countries but loose in developing countries, and that the coupling gets tighter as a country's level of development increases. The results are robust with respect to the classification of countries as developing versus developed. The indicators of entrepreneurship policy are sufficiently reliable and valid to yield strong and robust results, but they are not excellent. It will be appropriate for further research to include also other indicators of entrepreneurship policy.

The results support the view that the formation of national entrepreneurship policies cannot be explained merely from a functional perspective. Rather, policymaking is highly influenced by rationalized local politicians enacting scripts from legitimized world-models. As this enactment occurs, isomorphic processes will in particular have a high impact on developing countries. Institutional pressures will tend to drive policy makers in developing countries towards adopting policies from world models; world models dominated by experiences from 
developed countries and which potentially have a poor fit with the local social, political, and economic infrastructures of developing countries. Therefore, and because the scarcity of resources in general and the stage of development of institutional infrastructure in developing countries pre-empt policy programs from the world model from being fully implemented in practice, policy making in developing countries often take on a highly ritualistic and symbolic character. Consequently, there will be a loose coupling between entrepreneurship policy and entrepreneurship activity.

Solving the problem of loose coupling between policy and entrepreneurship activity in developing countries likely involves profound changes in the institutional structure of the global political and scientific community. It is imperative that developing nations do not give in to the temptation to mimic the policies of successful developed countries, but instead critically consider if and how scripts from world models can be adjusted to fit the current state of economic development. Likewise, to reduce cohesive isomorphism, it is important that powerful global institutions such as the UN etc. similarly recognize that experiences from successful developing countries may not readily transfer to developing countries.

For this to come through, a big task lies ahead for future research on public policy and entrepreneurship in systematically examining differences between different stages of economic development (van Stel et al., 2005). Such effort could certainly benefit from a tighter coupling between science and practice in the developing countries. Yet, it would also benefit from a tighter coupling within the science community consistent of research institutions etc. from developing countries. Just as the diffusion of world models is a highly associational process, so is their formation (Meyer et al., 1997). Studies have shown that scientists in sub-Saharan Africa (Rossum and Hicks, 1997) and in Latin American countries (Schøtt, 1995; Velho, 1986) have only little interaction among themselves. A stronger coupling between science institutions from countries at similar stages of economic development and with similar economic, political and cultural infrastructures would likely improve not only the quality of entrepreneurship research in developing countries. It would also facilitate that successful scripts, such as the Grameen Banking from India, more easily will find their way into becoming part of world models enacted by policy-makers in developing countries.

\section{REFERENCES}

Acs, Z. J. (1984). The Changing Structure of the U.S. Economy, New York: Praeger.

Acs, Z. J. and Audretsch, D. B. (2003). "Innovation and technological change", in: Z. J. Acs and D. B. Audretsch (eds.), Handbook of Entrepreneurship Research, Boston: Kluwer Academic Publishers, 55-79.

Acs, Z. J. and Szerb, L. (2007). "Entrepreneurship, Economic Growth and Public Policy”, Small Business Economics 28: 109-122.

Audretsch, D. B. and Thurik, A. R. (2001). "What is New about the New Economy: Sources of Growth in the Managed and Entrepreneurial Economies", Industrial and Corporate Change 10: 267-315. 
Brett, A. G.; Audretsch, D. B. and McDougall, P. P. (2004). "The Emergence of Entrepreneurship Policy”, Small Business Economics 22: 313-323.

Carree, M. A. and Thurik, A. R. (1999). "Industrial Structure and Economic Growth", in D. B. Audretsch and A. R. Thurik (eds.), Innovation, Industry Evolution and Employment, Cambridge: Cambridge University Press, 86-110.

Carree, M. A. and Thurik, R. (2003). "The Impact of Entrepreneurship on Economic Growth", in David B. Audretsch and Zoltan J. Acs (eds.), Handbook of Entrepreneurship Research, Boston/Dordrecht:KluwerAcademic Publishers, 437-471.

Drori, G. S. (2003). "Loose Coupling in National Science: Policy versus Practice", in Drori, G. S.; Meyer, J. W.; Ramirez, F. O. and Schofer, E. (eds.), Science in the Modern World Polity: Institutionalization and Globalization, Stanford University Press.

DiMaggio, P. J. and Powell, W. (1983). "The Iron Cage Revisited: Institutional Isomorphism and collective rationality in organizational fields", American Sociological Review, 48: 147-160.

Easterly, W. (2001). “The Lost Decades: Developing Countries' Stagnation in Spite of Policy Reform 1980-1998", Journal of Economic Growth, 6: $135-157$.

Gilbert, B. A.; Audretsch, D. B. and McDougall, P. P. (2004). "The Emergence of Entrepreneurship Policy", Small Business Economics, 22: 313-323.

Glassman, R. B. (1973). "Persistence and loose coupling in living systems", Behavioral Science, 18: 83-98.

Huber, G. P. (2004). The Necessary Nature of Future Firms: Attributes of Survivors in a Changing World. Sage Publications, Inc.

Human Development Report (2006). Published for the United Nations Development Programme (UNDP), Palgrave, Macmillan.

Kauffman Foundation (2006). Roadmap for an Entrepreneurial Economy.

Meyer, J. W.; Boli, J. and Chase, C. (1975). "Convergence and Divergence in Development”, Annual Review of Sociology, 1: 223-46.

Meyer, J. W.; Boli, J.; Thomas, G. M. and Ramirez, F. O. (1997). "World Society and the Nation-State", The American Journal of Sociology, 103 (1): 144-181.

Orton, J. D. and Weick, K. E. (1990). "Loosely Coupled Systems: A Reconceptualization", Academy of Management Review, 15 (2): 203-223.

Pfeffer, J. and Salancik, G. R. (1978). “The external control of organizations”, San Francisco: Harper \& Row.

Rossum, W. and Hicks, E. K. (1997). "Social and economic scientistsin sub-Saharan Africa and the flow of scientific information: A network study". Paper presented at the Sunbelt 17th International Social Network Conference, San Diego, Calif. November 1997.

Schøtt, T. (1995). "Performance, specialization and international integration of science in Brazil: changes and comparisons with other Latin American countries and Israel", in S. Schwartzman (coord.); Bertero, C.; Guimaraes, E.; Krieger, E.; Skolnikoff, E.; Gallembeck, F.; Ferné, G.; Branscomb, L.; Gibbons, M., and Schøtt, T., Science and Technology in Brazil: A New Policy for a Global World. Rio de Janeiro: Fundaçao Getulio Vargas, 227-284. 
Stel, A.; Carree, M. and Thurik, R. (2005). "The effect of entrepreneurial activity on economic growth", Small Business Economics, 24: 311-321.

Velho, L. (1986). "The "meaning' of citation in the context of the scientifically peripheral country". Scientometrics 2: 74-89.

Weick, K. E. (1976). "Educational organizations as loosely coupled systems", Administrative Science Quarterly, 21: 1-19.

Weick, K. E. (1982). "Management of organizational change among loosely coupled elements", in Goodman, P. S. \& Associates (eds.), Change in organizations. San Francisco: Jossey-Bass.

Wennekers, S.; van Stel, A.; Thurik, R. and Reynolds, P. (2005). "Nascent Entrepreneurship and the Level of Economic Development", Small Business Economics, 24: 293-309. 